\title{
Noncompetitive nature of oxytocin antagonists with general structure $\mathrm{Mpa}^{1} \mathrm{Xxx}^{2} \mathrm{Sar}^{7} \mathrm{Arg}^{8}$
}

\author{
J. Havass ${ }^{\text {a }}$, K. Bakos ${ }^{\text {b }, ~ A ́ . ~ M a ́ r k i ~ a ~}{ }^{\text {, R. Gáspár }}{ }^{\text {a }}$, L. Gera ${ }^{\text {c }}$, J.M. Stewart ${ }^{\text {c }}$, F. Fülöp ${ }^{\text {d }}$, \\ G.K. Tóth ${ }^{\mathrm{b}}$, I. Zupkó ${ }^{\mathrm{a}}$, G. Falkay ${ }^{\mathrm{a}, *}$ \\ a Department of Pharmacodynamics and Biopharmacy, University of Szeged, P.O. Box 121, Eötvös u. 6, H-6720 Szeged, Hungary \\ ${ }^{\mathrm{b}}$ Department of Medical Chemistry, University of Szeged, Dóm tér 8, H-6720 Szeged, Hungary \\ ${ }^{\mathrm{c}}$ Department of Biochemistry and Molecular Genetics, University of Colorado School of Medicine, 4200 E. Ninth Avenue, Denver, CO 80262, USA \\ ${ }^{\mathrm{d}}$ Department of Pharmaceutical Chemistry, University of Szeged, Eötvös u. 6, H-6720 Szeged, Hungary
}

Received 30 October 2001; accepted 20 February 2002

\begin{abstract}
Eight oxytocin (OT) antagonists with general structure $\mathrm{Mpa}^{1} \mathrm{Sar}^{7} \mathrm{Arg}^{8}$, substituted at position 2 with conformationally constrained and bulky amino acids, were synthesized and pharmacologically tested. Binding affinities and selectivities of compounds for OT, and vasopressin receptor subtypes were investigated. In vitro effects of antagonists were evaluated via inhibition of OT-induced contractions of isolated guinea-pig uterus. The abilities of OT antagonists to inhibit spontaneous contractility in $24 \mathrm{~h}$ postpartum rat uterus were investigated. These peptides exhibited pseudoirreversible pharmacological properties, and comprise a novel group of OT antagonists for potential clinical use. Their noncompetitive pharmacological nature can be of therapeutic benefit through a sustained effect on myometrium.
\end{abstract}

(C) 2002 Elsevier Science Inc. All rights reserved.

Keywords: Oxytocin antagonist; Noncompetitive; Tocolysis

\section{Introduction}

Although the average duration of gestation in women is 40 weeks, it is estimated that nearly 13 million babies are born preterm worldwide each year. The considerable variability in the timing of childbirth poses particular problems for both mother and baby: the shorter the gestation, the greater the likelihood of perinatal mortality and morbidity. Preterm birth remains the leading cause of neonatal mortality and morbidity [20].

The causes of preterm labor are still not known, and the relative effectiveness and safety of the various therapies are

Abbreviations: D-Igl, D-indanylglycine; MeOAtc, 6-methoxy-2aminotetraline-2-carboxylic acid, Pff, D- and L-pentafluorophenylalanine; Dmf, 2,4-dimethylphenylalanine; Tmf, 2,4,6,-trimethylphenylalanine; Land D-MeTcc, 1,2,3,4-tetrahydro-1-methyl- $\beta$-carboline-3-carboxylic acid; Meb, $p$-methylbenzyl; Mpa, $\beta$-mercaptopropionic acid; Mca, $\beta$-mercapto$\beta, \beta$-cyclopentamethylenepropionic acid; Pen, $\beta^{\prime}$-dimethylcysteine; Tos, tosyl; Boc, $N$-tert-butyloxycarbonyl; $p$ MBHA, $p$-methylbenzhydrylamine; DCC, $N, N^{\prime}$-dicyclohexylcarbodiimide; HPLC, high-performance liquid chromatography; PMSF, phenylmethylsulfonyl fluoride

* Corresponding author. Tel.: +36-62-545567; fax: +36-62-545567.

E-mail address: falkay@pharma.szote.u-szeged.hu (G. Falkay). unclear. The major form of treatment currently applied in cases of preterm labor is the administration of selective $\beta_{2}$-adrenergic agonists that inhibit myometrial contractility by activation of the receptor-mediated adenylcyclase cascade. Unfortunately, the use of these agents is associated with significant maternal and fetal side-effects [2,21]. Although other compounds have also been utilized for tocolysis, questions remain as concerns their efficacy and safety. It is evident that an effective tocolytic agent that has few or no side-effects would be extremely valuable.

Although the causes of preterm labor are multifactorial, it is becoming increasingly apparent that oxytocin (OT) has an important role in preterm labor. It is accepted that both OT itself and the sensitivity of the uterus to OT play crucial roles in the initiation of both normal and pathologically early deliveries $[3,19]$. The uterus contains OT and vasopressin (VP) receptors. VP likewise stimulates uterine contractions, but it is not known whether the uterotonic action of VP is mediated by the $\mathrm{VP}_{1 \mathrm{a}}$ receptor alone or also by the OT receptor (OTR).

Blockade of the uterine OTR is one of the logical approaches to the prevention of preterm labor. Over the past decade, a number of potent OTR antagonists have 
been developed and studied in animal models, Atosiban ${ }^{\mathrm{R}}$ ([1-deamino-D-Tyr $\left.\left.(\mathrm{OEt})^{2}-\mathrm{Thr}^{4} \mathrm{Orn}^{8}\right] \mathrm{OT}\right)$, is the first OT antagonist to be licensed for the treatment of preterm labor [5].

This study reports on the synthesis and in vitro and in vivo pharmacological investigations of new OT antagonists with the general structure $\left[\mathrm{Mpa} 1 \mathrm{Xxx}^{2} \mathrm{Sar}^{7} \mathrm{Arg}^{8}\right] \mathrm{OT}$, substituted at position 2 with conformationally constrained and bulky amino acids.

\section{Materials and methods}

\subsection{Animals}

Animal investigations were carried out with the approval of the Ethical Committee for Animal Research, University of Szeged (registration number 23/1999), in accordance with the Guiding Principles for the Care and Use of Research Animals. Sexually mature female Sprague-Dawley rats (body mass: 200-300 g) and Charles Liver guinea-pigs were used in the experiments. Mating with males was carried out in the early morning hours. Copulation was justified by the presence of a copulation plug or spermatozoa in the vagina. The day of conception was considered to be the first day of pregnancy. Animals were housed in temperature and humidity-controlled, light-regulated $(12 \mathrm{~h}$ of light, $12 \mathrm{~h}$ of dark) rooms, with water and food intake ad libitum.

\subsection{Peptide synthesis}

The syntheses of these peptides were earlier described in Letters in Peptide Synthesis [1]. Briefly, the peptides were synthesized by a solid-phase peptide technique, utilizing Boc chemistry. Side-chain protecting groups were as follows: $\operatorname{Arg}(\mathrm{Tos}), \mathrm{Cys}(\mathrm{Meb})$ and $\mathrm{Mpa}(\mathrm{Meb})$. The peptide chains were elongated on $p$-methylbenzhydrylamine ( $p$ MBHA) resin $(0.31-1.1 \mathrm{mmol} / \mathrm{g})$. Couplings were performed with DCC, with the exceptions of Asn, Gln and Arg, which were incorporated as their 1-hydroxybenzotriazole esters. Amino acid incorporation was monitored via the ninhydrin test. The completed peptide resins were treated with liquid $\mathrm{HF} /$ dimethyl sulfide/ $p$-cresol/anisole/ $p$-thiocresol (93:4:1:1:1, v/v) at $0{ }^{\circ} \mathrm{C}$ for $1 \mathrm{~h}$. The $\mathrm{HF}$ was removed and the resulting free peptides were solubilized in $10 \%$ aqueous acetic acid $(1 \mathrm{mg} / 10 \mathrm{ml})$ and folded by stirring with $0.01 \mathrm{M}$ potassium hexacyanoferrate(III). The completion of disulfide formation was monitored by means of HPLC. After it was complete, the solution was lyophilized.

The crude peptides were purified by reverse-phase HPLC (RP-HPLC) on a Lichrosorb RP-18 10 $\mu$ column $(16 \mathrm{~mm} \times$ $250 \mathrm{~mm}$ ). The purity was checked by RP-HPLC. The products proved to be substantially pure (>95\%).

The structures of the new analogs were proved by mass spectrometry.

\subsection{Membrane preparation}

The affinities and the selectivities of the synthesized peptides for the OTR and VP receptors (VPR) were determined by radioligand binding assay.

The OTR binding assays were carried out on a uterine plasma membrane fraction of term pregnant guinea-pig uterus. The plasma membrane was prepared by a modification of the previously described method [4]. Uterine tissue was minced and homogenized in $10 \mathrm{vol}$. ice-cold buffer containing $10 \mathrm{mM}$ Tris-HCl, $1.5 \mathrm{mM}$ EDTA, $0.5 \mathrm{mM}$ dithiotreitol and $1 \mathrm{mM}$ phenylmethylsulphonyl fluoride (PMSF); $\mathrm{pH}$ 7.5. After homogenization with an Ultra Turrax homogenizer, the suspension was centrifuged at $1000 \times g$ for $10 \mathrm{~min}$ at $4{ }^{\circ} \mathrm{C}$. The resultant supernatant was centrifuged at $100000 \times g$ for $60 \mathrm{~min}$ at $4{ }^{\circ} \mathrm{C}$. The pellets were washed and resuspended for storage in $\mathrm{Ca}^{2+}$-free Hanks' salt solution with $1 \mathrm{mM}$ PMSF at a protein concentration of approximately $10 \mathrm{mg} / \mathrm{ml}$ at $-70^{\circ} \mathrm{C}$.

Rat kidney inner medulla containing $\mathrm{VP}_{2}$ receptors and rat liver plasma containing $\mathrm{VP}_{1}$ receptors were prepared by the following method [14]. Adult male Sprague-Dawley rats $(200-300 \mathrm{~g})$ were killed by stunning and decapitation. The medullopapillary region of the kidneys and the livers were homogenized with an Ultra Turrax in 20 vol. ice-cold buffer containing $10 \mathrm{mM}$ Tris- $\mathrm{HCl}$ and $0.1 \mathrm{mM}$ PMSF; $\mathrm{pH}$ 7.4. The homogenate was centrifuged at $500 \times g$ for $5 \mathrm{~min}$ to remove all debris and nuclei. The supernatant was centrifuged at $20000 \times g$ for $20 \mathrm{~min}$, and the pellet was resuspended in ice-cold incubation buffer containing $100 \mathrm{mM}$ Tris- $\mathrm{HCl}$ (pH 7.4), $10 \mathrm{mM} \mathrm{MgCl} 2,0.5 \mathrm{mg} / \mathrm{ml}$ bacitracin and $100 \mathrm{IU} / \mathrm{ml}$ aprotinin, and recentrifuged at $20000 \times g$. The final pellet was resuspended for storage in 10 vol. incubation buffer.

\subsection{Receptor assays}

The affinities of OT and its analogs for the OTR and VPRs were determined by heterolog displacement analyses. In the OTR assay, the assay buffer consisted of $25 \mathrm{mM}$ Tris- $\mathrm{HCl}$, $1 \mathrm{mM} \mathrm{MnCl} 2,1 \mathrm{mM}$ PMSF and $0.1 \% \mathrm{BSA}$; $\mathrm{pH}$ 7.5. The affinities of the OT analogs were investigated in the presence of $1 \mathrm{nM}\left[{ }^{3} \mathrm{H}\right]$ oxytocin $(44 \mathrm{Ci} / \mathrm{mmol})$ at $22^{\circ} \mathrm{C}$ for $60 \mathrm{~min}$. In the VPR assay, the assay buffer contained $100 \mathrm{mM}$ Tris- $\mathrm{HCl}, 10 \mathrm{mM} \mathrm{MgCl} 2,0.5 \mathrm{mg} / \mathrm{ml}$ bacitracin, $100 \mathrm{IU} / \mathrm{ml}$ aprotinin and $0.1 \%$ BSA. The competition binding assays were carried out in the presence of $1 \mathrm{nM}\left[{ }^{3} \mathrm{H}\right]$ vasopressin $(75 \mathrm{Ci} / \mathrm{mmol})$ at $25^{\circ} \mathrm{C}$ for $120 \mathrm{~min}$. In both cases, the nonspecific binding was determined in the presence of $10^{-5} \mathrm{M}$ unlabeled OT and VP. The bound ligand was separated from the free ligand by rapid filtration through a Whatman GF/C glass fiber filter, using a Brandel M24R cell harvester. Specific binding was determined by subtracting the nonspecific binding from the total binding. All assays were carried out at least three times in duplicate and values were given as means \pm S.E.M. Binding parameters were calculated 
with the Prism 2.01 (GraphPad Software, USA) computer program.

\subsection{Measurement of uterine contraction in vitro}

Uteri were removed from 60 to 65-day pregnant guinea-pigs, and trimmed of fat, the feto-placental units were removed and the decidua was scraped off. A uterine muscle strip (10 mm long and $10 \mathrm{~mm}$ wide) was suspended vertically in a $10 \mathrm{ml}$ organ bath containing Van Dyke-Hastings solution [8]. The bath temperature was maintained at $37^{\circ} \mathrm{C}$ and $\mathrm{O}_{2}: \mathrm{CO}_{2}(95 \%: 5 \%)$ was bubbled through the solution. The initial tension was set at $1.0 \mathrm{~g}$.

The uterine strips were equilibrated for $60 \mathrm{~min}$ before the onset of the experiments and allowed to contract spontaneously and display stable rhythmic contractions. At the end of the adaptation period, the antagonists were added to the tissue bath. After a $30 \mathrm{~min}$ incubation in the presence of the antagonist, increasing doses ranging from $10^{-9}$ to $10^{-3} \mathrm{M}$ OT were administered. The contractions were measured with a strain gauge transducer (SG-02, Experimetria UK Ltd.) and recorded by an ISOSYS Data Acquisition System (Experimetria UK Ltd.). The contractile response to OT was measured as the area under the curve during a 3 min period. Areas under curves were evaluated with the computer program as mentioned above. For statistical evaluations, data were analyzed by means of the ANOVA; post hoc comparisons were performed with the Newman-Keuls test.

\subsection{Measurement of uterine contraction in vivo}

Twenty-four hours after spontaneous delivery, female Sprague-Dawley rats were anesthetized with urethane ( $1 \mathrm{~g} / \mathrm{kg}$, i.p.). After cannulation of the jugular vein, a Millar catheter (Millar Instruments Inc., Houston, TX, USA) fitted with a liquid-filled latex microballoon was inserted into the uterine horn through a small section above the cervical part. At the end of the $30 \mathrm{~min}$ equilibration period, the intrauterine pressure was recorded and the effects of the intravenously administered compounds were assessed by expressing the integrated tension relating to a $5 \mathrm{~min}$ period after the administration of each dose as a percentage of the average for three $5 \mathrm{~min}$ periods before the first administration. The maximum inhibition and the $\mathrm{ED}_{50}$ values were calculated. Statistical analysis was carried out as mentioned above.

\section{Results}

\subsection{Receptor binding}

The synthesized OT antagonists contained different cyclic $\alpha$-amino acids at position 2: D-indanylglycine (D-Igl), 6-methoxy-2-aminotetraline-2-carboxylic acid (MeOAtc), D- and L-pentafluorophenylalanine (Pff), 2,4-dimethylphenylalanine (Dmf), 2,4,6,-trimethylphenylalanine (Tmf), and conformationally constrained derivatives of tryptophan: 1,2,3,4-tetrahydro-1-methyl- $\beta$-carboline-3-carboxylic acid (L- and D-MeTcc) (Fig. 1).

OT was found to bind to the guinea-pig uterine OTR with a dissociation constant of $2.51 \pm 0.6 \mathrm{nM}$. The inhibition constants $\left(K_{\mathrm{i}}\right)$ of the tested OT antagonists relative to the OT, $\mathrm{VP}_{1}$ and $\mathrm{VP}_{2}$ receptors are listed in Table 1. For comparison, atosiban was tested in the same system. Each drug displaced the tritiated OT binding in a concentration-dependent manner.

The $K_{\mathrm{i}}$ values of three newly synthesized analogs for the OTR were similar to that of atosiban. Substitution at<smiles>Cc1ccc(CC(N)C(=O)O)c(C)c1</smiles>

Dmf<smiles>Cc1cc(C)c(CC(N)C(=O)O)c(C)c1</smiles>

Tmf<smiles>NC(C(=O)O)C1Cc2ccccc2C1</smiles>

D-Igl<smiles>NC(Cc1c(F)c(F)c(F)c(F)c1F)C(=O)O</smiles>

Pff<smiles>COc1ccc2c(c1)CCC(N)(C(=O)O)C2</smiles>

MeOAtc

Fig. 1. Amino acids incorporated at position 2. 
Table 1

$K_{\mathrm{i}}$ values of the tested peptides for the $\mathrm{OT}, \mathrm{VP}_{1}$ and $\mathrm{VP}_{2}$ receptors

\begin{tabular}{|c|c|c|c|}
\hline \multirow[t]{2}{*}{ OT antagonists } & \multicolumn{3}{|c|}{$K_{\mathrm{i}}$ values $(\mathrm{nM} \pm$ S.E.M.) } \\
\hline & OTR & $\mathrm{VP}_{1}$ receptor & $\mathrm{VP}_{2}$ receptor \\
\hline Atosiban & $5.76 \pm 1.48$ & $1412 \pm 145$ & $667 \pm 163$ \\
\hline$\left[\mathrm{Mpa}^{1}, \mathbf{D m f}^{2}, \mathrm{Sar}^{7}, \mathrm{Arg}^{8}\right] \mathrm{OT}^{\mathrm{a}}$ & $1.49 \pm 0.31$ & $48.4 \pm 25.7$ & $70.8 \pm 15.8$ \\
\hline$\left[\mathrm{Mpa}^{1}, \mathbf{d}-\mathbf{I g l}^{2}, \mathrm{Sar}^{7}, \mathrm{Arg}^{8}\right] \mathrm{OT}$ & $3.81 \pm 0.18$ & $263 \pm 36.9$ & $425 \pm 29.1$ \\
\hline$\left[\mathrm{Mpa}^{1}, \mathbf{T m f}^{2}, \mathrm{Sar}^{7}, \mathrm{Arg}^{8}\right] \mathrm{OT}^{\mathrm{a}}$ & $46.5 \pm 19.6$ & $254 \pm 128$ & $384 \pm 99.3$ \\
\hline$\left[\mathrm{Mpa}^{1}, \mathbf{d}-\mathbf{P f f}^{2}, \mathrm{Sar}^{7}, \mathrm{Arg}^{8}\right] \mathrm{OT}$ & $52.9 \pm 20.5$ & $5420 \pm 2490$ & $2250 \pm 820$ \\
\hline$\left[\mathrm{Mpa}^{1}\right.$, MeOAtc $\left.^{2}, \operatorname{Sar}^{7}, \operatorname{Arg}^{8}\right] \mathrm{OT}^{\mathrm{a}}$ & $56.2 \pm 9.56$ & $1940 \pm 1230$ & $1640 \pm 1100$ \\
\hline$\left[\mathrm{Mpa}^{1}, \mathbf{l}-\mathbf{P f f}^{2}, \mathrm{Sar}^{7}, \mathrm{Arg}^{8}\right] \mathrm{OT}$ & $230 \pm 83.9$ & $3420 \pm 620$ & $9950 \pm 2470$ \\
\hline$\left[\mathrm{Mpa}^{1}, \mathbf{l}-\mathbf{M e T c c}^{2}, \mathrm{Sar}^{7}, \mathrm{Arg}^{8}\right] \mathrm{OT}$ & $2020 \pm 124$ & $3740 \pm 2850$ & $5400 \pm 590$ \\
\hline$\left[\mathrm{Mpa}^{1}, \mathbf{d}-\mathbf{M e T c c}^{2}, \mathrm{Sar}^{7}, \mathrm{Arg}^{8}\right] \mathrm{OT}$ & $4700 \pm 745$ & $9564 \pm 3412$ & $55100 \pm 6200$ \\
\hline
\end{tabular}

a The absolute configuration has not been determined.

position 2 with Dmf and D-Igl resulted in the compounds with the highest affinities.Incorporation of a further methyl group at position 6 of the phenylalanine ring (Tmf) decreased the affinity for the OTR.

As concerns Pff, the incorporation of the two configurations of the amino acids resulted in analogs with different affinities.

Substitution with the two configurations of the $\beta$-carboline derivatives led to the lowest affinities for the OTR.

Table 2 gives the selectivity ratios of the newly synthesized OT antagonists. The selectivity ratios were calculated from the $K_{\mathrm{i}}$ values for the OTR and the different types of VPRs.

None of the tested analogs had such a high selectivity as atosiban. However, five of them exhibited relatively good selectivities: $\left[\mathrm{Mpa}^{1}, \mathrm{D}-\mathrm{Pff}^{2}, \mathrm{Sar}^{7}, \mathrm{Arg}^{8}\right] \mathrm{OT},\left[\mathrm{Mpa}^{1}, \mathrm{D}-\mathrm{Igl}^{2}\right.$, $\left.\mathrm{Sar}^{7}, \mathrm{Arg}^{8}\right] \mathrm{OT},\left[\mathrm{Mpa}^{1}, \mathrm{MeoAtc}^{2}, \mathrm{Sar}^{7}, \mathrm{Arg}^{8}\right] \mathrm{OT},\left[\mathrm{Mpa}^{1}\right.$, $\left.\mathrm{Dmf}^{2}, \mathrm{Sar}^{7}, \mathrm{Arg}^{8}\right] \mathrm{OT}$ and $\left[\mathrm{Mpa}^{1}, \mathrm{~L}-\mathrm{Pff}^{2}, \mathrm{Sar}^{7}, \mathrm{Arg}^{8}\right] \mathrm{OT}$. This means that these compounds have affinities higher by two orders for the OTR than for the VPRs. $\left[\mathrm{Mpa}^{1}, \mathrm{Tmf}^{2}\right.$, $\left.\mathrm{Sar}^{7}, \mathrm{Arg}^{8}\right] \mathrm{OT},\left[\mathrm{Mpa}^{1}, \mathrm{D}-\mathrm{MeTcc}^{2}, \mathrm{Sar}^{7}, \mathrm{Arg}^{8}\right] \mathrm{OT}$ and $\left[\mathrm{Mpa}^{1}, \mathrm{~L}-\mathrm{MeTcc}^{2}, \mathrm{Sar}^{7}, \mathrm{Arg}^{8}\right]$ OT had weaker selectivities for the OTRs. With the exception of L-MeTcc, none of the

Table 2

Selectivity ratios of the tested peptides

\begin{tabular}{|c|c|c|}
\hline \multirow[t]{2}{*}{ OT antagonists } & \multicolumn{2}{|c|}{ Selectivity ratio } \\
\hline & $\mathrm{OT} \mathrm{VP}_{1}$ & $\mathrm{OT} / \mathrm{VP}_{2}$ \\
\hline Atosiban & 0.004 & 0.008 \\
\hline$\left[\mathrm{Mpa}^{1}, \mathbf{d}-\mathbf{P f f}^{2}, \mathrm{Sar}^{7}, \mathrm{Arg}^{8}\right] \mathrm{OT}$ & 0.010 & 0.023 \\
\hline$\left[\mathrm{Mpa}^{1}, \mathbf{d}-\mathbf{I g l}^{2}, \mathrm{Sar}^{7}, \mathrm{Arg}^{8}\right] \mathrm{OT}$ & 0.014 & 0.009 \\
\hline$\left[\mathrm{Mpa}^{1}, \mathrm{MeOAtc}^{2}, \mathrm{Sar}^{7}, \operatorname{Arg}^{8}\right] \mathrm{Ot}^{\mathrm{a}}$ & 0.029 & 0.034 \\
\hline$\left[\mathrm{Mpa}^{1}, \mathbf{D m f}^{2}, \mathrm{Sar}^{7}, \mathrm{Arg}^{8}\right] \mathrm{Ot}^{\mathrm{a}}$ & 0.031 & 0.021 \\
\hline$\left[\mathrm{Mpa}^{1}, \mathbf{l}-\mathbf{P f f} \mathbf{f}^{2}, \mathrm{Sar}^{7}, \mathrm{Arg}^{8}\right] \mathrm{OT}$ & 0.067 & 0.023 \\
\hline$\left[\mathrm{Mpa}^{1}, \mathbf{T m f}^{2}, \mathrm{Sar}^{7}, \mathrm{Arg}^{8}\right] \mathrm{Ot}^{\mathrm{a}}$ & 0.183 & 0.121 \\
\hline$\left[\mathrm{Mpa}^{1}, \mathbf{d}-\mathbf{M e T c c}^{2}, \mathrm{Sar}^{7}, \mathrm{Arg}^{8}\right] \mathrm{OT}$ & 0.491 & 0.085 \\
\hline$\left[\mathrm{Mpa}^{1}, \mathbf{l}-\mathbf{M e T c c}^{2}, \mathrm{Sar}^{7}, \mathrm{Arg}^{8}\right] \mathrm{OT}$ & 0.540 & 0.374 \\
\hline
\end{tabular}

${ }^{\mathrm{a}}$ The absolute configuration has not been determined. tested OT antagonists could differentiate between the two types of VPR.

\subsection{In vitro uterine contractility studies}

An initial series of studies was undertaken to determine the effects of the tested peptides on OT-induced contractions in isolated strips of pregnant guinea-pig uterus. OT induced dose-related increases in basal tone, amplitude and frequency of contraction, with maximum effects. In the presence of the newly synthesized OT antagonists, the maximum effects were significantly decreased, $F(9,72)=5.276, P<$ 0.0001 (Figs. 2 and 3).

In contrast, in the presence of atosiban, a higher concentration of OT was required to elicit the same degree of myometrial contractility. In isolated guinea-pig uterine strips, atosiban $\left(10^{-8} \mathrm{M}\right)$ displaced the OT dose-response curve to the right in a parallel fashion, without significant change in the maximum effect (Fig. 4).

\subsection{Uterine contractility in vivo}

The aim of the next series of experiments was to examine the ability of four newly synthesized OT antagonists to inhibit the spontaneous contractility in the $24 \mathrm{~h}$ postpartum rat uterus. Four compounds were selected on the basis of their good in vitro effectivities and were tested in an in vivo system. The OT antagonists were administered intravenously, in a cumulative manner (the first dose was $0.001 \mathrm{mg} / \mathrm{kg}$ ). All the tested peptides markedly suppressed the myometrial contraction in a dose-dependent way (Fig. 5).

The calculated maximum inhibition of the spontaneous uterine motility and $\mathrm{ED}_{50}$ values are listed in Table 3. For comparison, atosiban was tested in the same system.

These data demonstrate that all of the tested peptides are effective in inhibiting the spontaneous contractility of the rat uterus in vivo. The antioxytocic activity of the peptide substituted with Dmf at position 2 is comparable to that of atosiban. Incorporation of the other amino acids resulted 

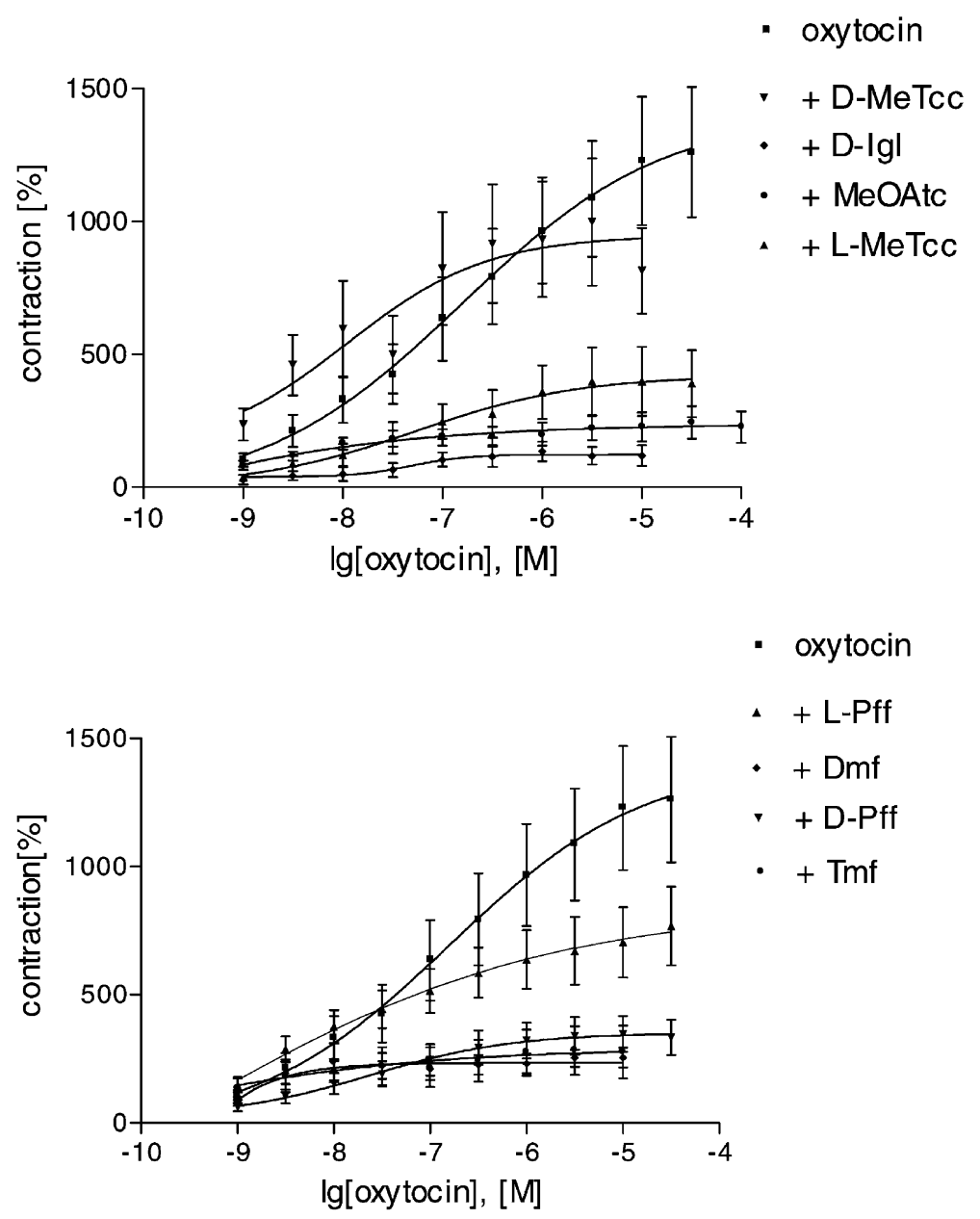

Fig. 2. The dose-response curves represent the effects of OT on isolated guinea-pig uterus alone and in the presence of the newly synthesized OT antagonists. The spontaneous uterine contractility was taken as $100 \%$. All of the tested peptides significantly decreased the maximum effect observed with OT, without any significant change in the $\mathrm{ED}_{50}$ value. (Values are given as means \pm S.E.M.).

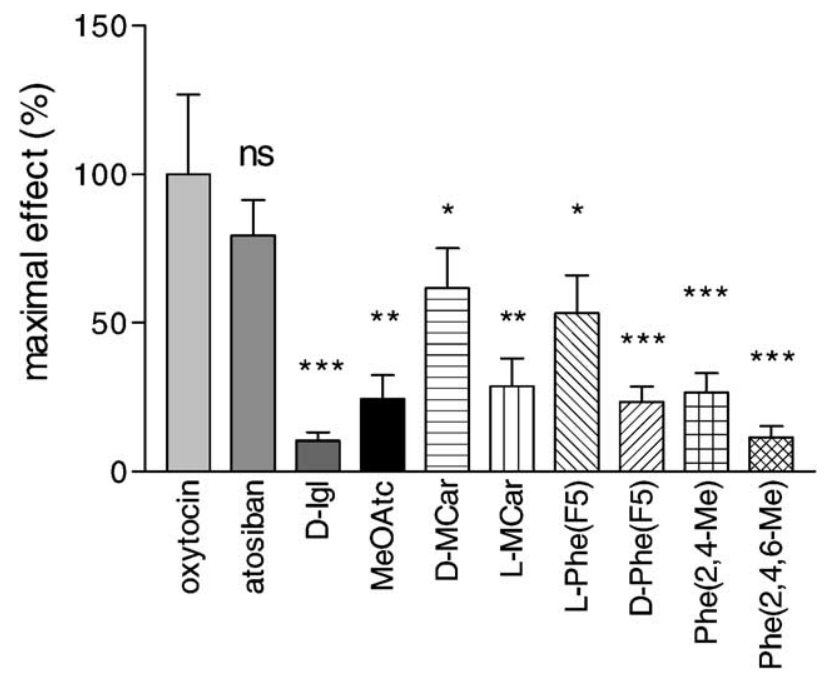

Fig. 3. Statistical comparison of the antioxytocic effects of the tested peptides. Each bar represents the maximum effects of OT alone and in the presence of the tested peptides in the isolated pregnant guinea-pig uterus (results of Newman-Keuls post hoc test, ns: not significant, $* P<0.05$; $* * P<0.01 ; * * * P<0.001)$.

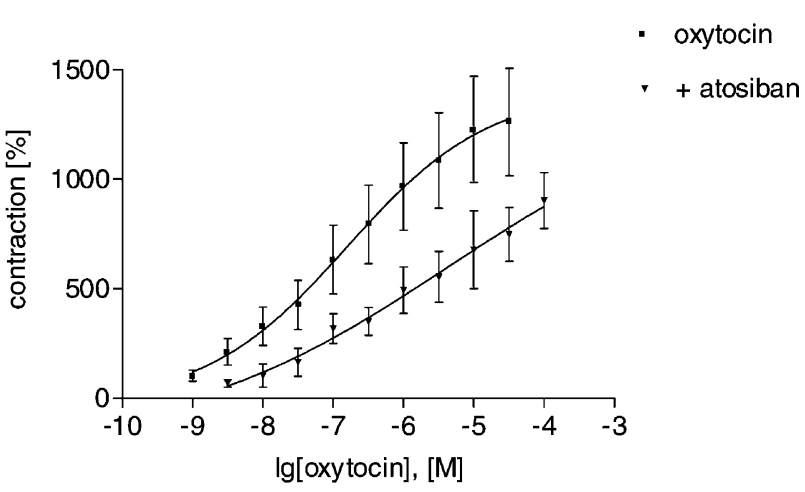

Fig. 4. The dose-response curves represent the effect of OT alone and in the presence of atosiban. The spontaneous uterine contractility was taken as $100 \%$. Atosiban did not decrease the maximum effect of OT, but significantly changed the $\mathrm{ED}_{50}$ of OT. (Values are given as means \pm S.E.M.). 


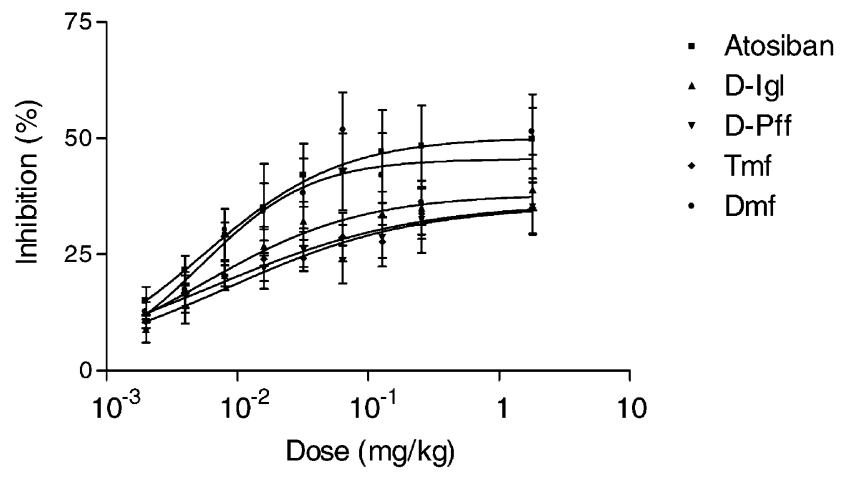

Fig. 5. The dose-response curves represent the inhibitory effects of the tested peptides on the postpartum rat in vivo. The tested peptides were given intravenously, in a cumulative way. (The data are the averages of the results of six independent experiments; values are given as means \pm S.E.M.).

Table 3

Calculated maximum inhibition and $\mathrm{ED}_{50}$ values of the tested peptides

\begin{tabular}{lll}
\hline OT antagonists & Maximal effect $(\%)$ & $\mathrm{ED}_{50}(\mu \mathrm{g} / \mathrm{kg})$ \\
\hline Atosiban & 50.23 & 5.568 \\
{$\left[\mathrm{Mpa}^{1}, \mathbf{d}-\mathbf{P f f}^{2}, \mathrm{Sar}^{7}, \mathrm{Arg}^{8}\right] \mathrm{OT}$} & 35.22 & 8.293 \\
{$\left[\mathrm{Mpa}^{1}, \mathbf{d}-\mathbf{I g l}^{2}, \mathrm{Sar}^{7}, \mathrm{Arg}^{8}\right] \mathrm{OT}$} & 38.04 & 6.276 \\
{$\left[\mathrm{Mpa}^{1}, \mathbf{D m f}^{\mathbf{2}}, \mathrm{Sar}^{7}, \mathrm{Arg}^{8}\right] \mathrm{OT}$} & 45.57 & 5.330 \\
{$\left[\mathrm{Mpa}^{1}, \mathbf{T m f}^{2}, \mathrm{Sar}^{7}, \mathrm{Arg}^{8}\right] \mathrm{OT}$} & 36.18 & 6.449 \\
\hline
\end{tabular}

in analogs with moderate activities. There were no marked differences in the $\mathrm{ED}_{50}$ values.

\section{Discussion}

Although the role of OT in the spontaneous onset of labor remains controversial, it may be concluded that OT antagonists offer a potentially useful approach for the management or even the prevention of uncomplicated preterm labor. The primary attraction is their apparent myometrial selectivity and the lack of side-effects as compared with other available therapies, e.g. $\beta$-mimetics. A number of studies have dealt with the design and pharmacological investigation of new OT antagonists. During the development of the OT antagonists, modification of the OT molecule at positions $1,2,4$ or 7 and 8 produced analogs with higher receptor affinities for the myometrium in vitro $[6,7,10,15,16]$. The most potent of these was atosiban, which subsequently underwent clinical evaluation.

These synthesized peptides are 1-deamino-7-sarcosine-8arginine analogs. It was observed in previous studies [22] that appropriate modification of the Tyr at position 2 plays a crucial role in determining the antagonistic property. Our approaches in the design of more effective OT antagonists are based mainly on the incorporation of bulky apolar side-chain amino acids with a conformationally constrained restricted feature at position 2 [9,11-13]. These small peptides are rather flexible molecules, and their three-dimensional structure depends highly on the environment in solution. We attempted to restrict this relatively extensive conformational freedom in order to stabilize the bioactive antioxytocic conformation. Such conformational restriction can be achieved by incorporating a second intramolecular ring or a substituent involving a constrained amino acid [18].

The results of receptor analyses indicate that the OT antagonists containing phenylalanine derivatives at position 2 have higher affinities for the OTR than those containing tryptophan analogs. It is conceivable that the incorporation of a tryptophan analogue into the peptide results in a molecule that is too large and rigid to bind to the apolar side-chain binding pocket of the OTR. In order to achieve better affinity, different phenylalanine derivatives were synthesized for incorporation. Of these compounds, Dmf and D-Igl resulted in the compounds with the highest affinities, similar to that of atosiban. Incorporation of a further methyl group into position 6 of the phenylalanine ring (Tmf) decreased the affinity for the OTR and destroyed the selectivity too. Substitution of the phenylalanine ring with halogen atoms decreased the affinity for the OTR. The binding to the OTR of the D isomer of this phenyalanine derivative is higher than in the case of the $\mathrm{L}$ isomer. The 6-methoxy-2-aminotetraline-2-carboxylic acid derivative was designed by modification of a previously synthesized and investigated OT antagonist containing aminotetralinecarboxylic acid at position 2. The new OT antagonist, $\left[\mathrm{Mpa}^{1}, \mathrm{MeOAtc}^{2}, \mathrm{Sar}^{7}, \mathrm{Arg}^{8}\right] \mathrm{OT}$, has higher affinity and selectivity than those of the original molecule. The presence of the methoxy at position 6 of the tetraline ring improves the interaction of the analog and the OTR.

The rationale for the development of OT antagonists was based on producing a novel compound that mimicked normal physiological processes with high uterine specificity, but with limited or no systemic effects. The specificity for the OTR in the uterus is the key to the clinical application of the OT antagonists, since the major problem with all current tocolytic agents is their systemic activity, which causes potentially harmful multiorgan side-effects. All of the newly synthesized OT antagonists exhibit OTR selectivity, but lower than that of atosiban. Incorporation of D-Igl and D-Pff at position 2 resulted in the most selective compounds. The analogs containing an amino acid with the $\mathrm{L}$ or $\mathrm{D}$ configuration at position 2 proved to be less selective than their diastereomers, so the L or D configuration at this site is unfavorable for good selectivity.

The results of the in vitro contractility study indicated that all the tested peptides were noncompetitive antagonists, in contrast with atosiban, which is a competitive one [17]. This pharmacological characteristic can not be explained by the chemical features of these peptides. Washing experiments demonstrated that none of the synthesized OT antagonists can produce an irreversible interaction to the binding sites of the OTR and VPRs. Pregnant guinea-pig uterine membrane was preincubated in the presence of the tested peptides 
for $30 \mathrm{~min}$ at $37^{\circ} \mathrm{C}$, and the specific binding was then measured as described in Section 2. The remainder of the preincubated membrane fraction was diluted to a 15 -fold volume and centrifuged, and the specific binding was measured again. This dilution-centrifugation-binding procedure was performed three times. There was no significant decrease in the specific binding sites. Consequently, this noncompetitive antagonism is due to the size and structure of the apolar side-chain of the amino acid at position 2. In the new peptides, the amino acids at this position are more conformationally constrained than that in atosiban, which can explain their behavior.

The results of the in vivo experiments support the pharmacological antagonistic nature of these peptides. All of the tested peptides inhibited the intrinsic OT-induced contraction in a dose-dependent manner. The incorporation of Dmf resulted in the most effective OT antagonist among the tested peptides. This may be due to the size and the arrangement of the side-chain of the amino acids at position 2 . The phenylalanine ring substituted at positions 2 and 4 with methyl groups is needed for strong antioxytocic activity.

As regards these syntheses of OT antagonists, the incorporation of Dmf at position 2 resulted in a peptide that was nearly equipotent to atosiban. These two compounds have similar affinities for the OTR and inhibitory effects in the in vivo system. However, atosiban has a better selectivity for the OTR.

In consequence of their pseudoirreversible pharmacological properties, these peptides comprise a novel group of OT antagonists for potential clinical use. This noncompetitive pharmacological nature may be of therapeutic benefit because of the sustained effect on the myometrium. In the near future, a well-tolerated, effective, specific and rationally designed tocolytic agent may change the procedure of tocolysis. The noncompetitive OT antagonists may be among such promising drug novelties.

\section{References}

[1] Bakos K, Havass J, Fülöp F, Gera L, Stewart JM, Falkay G. Synthesis and receptor binding of oxytocin analogs containing conformationally restricted amino acids. Letters in peptides 2002;8:35-40.

[2] Caritis SN, Darby MJ, Chan L. Pharmacologic treatment of preterm labor. Clin Obstet Gynecol 1988;31:635-51.

[3] Fuchs AR, Fuchs F, Husslein P, Soloff MS, Fernstrom MJ. Oxytocin receptors and human parturition: a dual role for oxytocin in the initiation of labor. Science 1982;215:1396-8.

[4] Fuchs AR, Helmer H, Behrens O, Liu HC, Antonian L, Chang SM, et al. Oxytocin and bovine parturition: a steep rise in endometrial oxytocin receptors precedes onset of labor. Biol Reprod 1992;47: 937-44.

[5] Goodwin TM, Valenzuela G, Silver H, Hayashi R, Creasy GW, Lane R. Treatment of preterm labor with oxytocin antagonist atosiban. Am J Perinatol 1996;13(3):143-6.
[6] Grzonka Z, Kasprzykowski F, Lubkowska L, Darlak K, Hahn TA, Spatola AF. In vitro degradation of some arginine-vasopressin analogs by homogenates of rat kidney, liver and serum. Pept Res 1991;4: 270-4.

[7] Grzonka Z, Lammek B, Kasprzykowski F, Gazis D, Schwartz IL. Synthesis and some pharmacological properties of oxytocin and vasopressin analogues with sarcosine or $N$-methyl-L-alanine in position 7. J Med Chem 1983;26:555-9.

[8] Hahn DW, Demarest KT, Ericson E, Homm RE, Capetola RJ, McGuire JL. Evaluation of 1-deamino-[D-Tyr(Oethyl $)^{2}, \mathrm{Thr}^{4}, \mathrm{Orn}^{8}$ ] vasotocin, an oxytocin antagonist, in animal models of uterine contractility and preterm labor: a new tocolytic agent. Am J Obstet Gynecol 1987;157(4):977-82.

[9] Hruby VJ, Chan WY, Rockway TW, Hlavacek J, Ormberg J. In: Basava C, Amantharamaiah GM, editors. In peptides: design, synthesis and biological activity, Boston: Birkhauser, 1994. p. $199-208$.

[10] Lebl M. Analogs with inhibitory properties. In: Jost K, Lebl M, Brtnik F, editors. Handbook of neurohypophyseal hormone analogs, vol. 2. Boca Raton: CRC Press, 1987. p. 17-74.

[11] Manning M, Cheng LL, Stoev S, Bankowski K, Przybyski $\mathrm{J}$, Klis WA, et al. An exploration of the effects of $\mathrm{L}-$ and D-terahydroisoquinoline-3-carboxylic acid substitutions at position 2, 3 and 7 in cyclic and linear antagonists of vasopressin and oxytocin and at position 3 in arginine vasopressin. J Pept Sci 1995;1(1): 66-79.

[12] Manning M, Krilszynski M, Bankowski K, Olma A, Lammek B, Chey LL, et al. Solid-phase synthesis of the effects of L- and D-terahydroisoquinoline-3-carboxylic acid substitutions at position 2, 3 and 7 in cyclic and linear antagonists of vasopressin and oxytocin and at position 3 in arginine vasopressin. J Med Chem 1989;32:38291.

[13] Manning M, Miteva K, Panchera S, Stoev WoNS, Chan WY. Design and synthesis of higher selectivity in vitro and in vivo uterine receptor antagonists of oxytocin comparison with atosiban. Int J Pept Protein Res 1995;46:244-52.

[14] Marchingo AJ, Abrahams JM, Woodcock EA, Smith AI, Mendelsohn FAO, Johnston CI. Properties of $\left[{ }^{3} \mathrm{H}\right] 1$-desamino-8-D-arginine vasopressin as a radioligand for vasopressin $\mathrm{V}_{2}$ receptors in rat kidney. Endocrinology 1988;122(4):1328-36.

[15] Melin P, Trojnar J, Johansson B, Vilhardt H, Akerlund M. Synthetic antagonists of the myometrial response to vasopressin and oxytocin. J Endocrinol 1986;111:1125-31.

[16] Pavó I, Slaninova J, Klein U, Fahrenholz F. Enhanced selectivity of oxytocin antagonists containing sarcosin at position 7. J Med Chem 1994;37:255-9.

[17] Phaneuf S, Asbóth G, MacKenzie IZ, Melin P, López Bernal A. Effect of oxytocin antagonists on the activation of human myometrium in vitro: atosiban prevents oxytocin-induced desensitization. Am J Obstet Gynecol 1994;171(6):1627-34.

[18] Smith DD, Slaninova J, Hruby VJ. Structure-activity studies of a novel bicyclic oxytocin antagonists. J Med Chem 1992;35:1558-63.

[19] Takahashi K, Diammond F, Bieniarz J, Yen H, Burd L. Uterine contractility and oxytocin sensitivity in preterm, term, and postterm pregnancy. Am J Obstet Gynecol 1980;136:774-9.

[20] Villar J, Ezcurra EJ, Gurtner de la Fuente V, Campodonico L. Preterm delivery syndrome: the unmet need. Res Clin Forums 1994;16:9-38.

[21] Wishnik A. Risk-benefit assessment of tocolytic drugs. Drug Saf 1991;6:372-80.

[22] Zupkó I, Tóth GK, Bakos K, Fülöp F, Pávó I, Havass J, et al. In vivo effects of 2 -substituted $\left[\mathrm{Mpa}^{1} \mathrm{Sar}^{7} \mathrm{Arg}^{8}\right]$-oxytocin antagonists on postpartum rat. Peptides 1999;20:749-51. 